\section{Research Article}

(C) 2021 Fofanah et al. This is an open access article licensed under the Creative Commons Attribution-NonCommercial 4.o International License (https://creativecommons.org/licenses/by-nc/4.o/)

\title{
Practitioners and Uses of Contemporary Mende Folk literature in South-Eastern Sierra Leone
}

\author{
Ibrahim Mustapha Fofanah ${ }^{1}$ \\ Dr. Philip Foday Yamba Thulla ${ }^{1}$ \\ Dr. Samba Moriba² \\ 'Institute of Languages and Cultural Studies, \\ Njala University, Njala Campus, \\ Bo, Sierra Leone \\ ${ }^{2}$ Freetown Teachers' College, \\ ${ }_{9} V_{3}+5 R W$, Hastings, \\ Sierra Leone
}

DOI: https://doi.org/10.36941/ajis-2021-0157

\begin{abstract}
The study examined the practitioners and uses of contemporary Mende folk literature in South-eastern Sierra Leone. A qualitative research design involving 250 participants from 50 communities with 5 participants from each community was used in the study. Interviews were carried out using interview guide questions relating to folk practices, performance, and uses in the selected communities. Focus group discussions followed the interviews in 10 communities selected using simple random techniques. The findings revealed that Mende folk literature was endangered and, apart from occasional singing, household story-telling and riddling sessions done mainly by children and women, the only groups of people recognized as practitioners of Mende folk literature were the tribal and secret society heads and the community's griots, who mostly were elderly people. Mende folk literature should not only be of academic interest but rather a source of cultural rejuvenation.
\end{abstract}

Keywords: Folk-literature, Folk Practitioners, Performance, Uses, Contemporary

\section{Introduction}

Like all other African countries, the folklore of the people of Sierra Leone remains a potent source of identity, recognition, education, solace, and entertainment. However, the clash between indigenous cultures with Western ones has affected the performance, enjoyment, and preservation of folk literature among the ethnic groups in Sierra Leone. This is why Sibani (2018) stated that Western culture had impacted the traditional African society tremendously in positive and negative dimensions, amongst which the rise of acculturation remains eminent. Sibani further noted that a critical look at the Western influence on African culture shows both good and bad consequences, making much of African native culture giving way to the European culture. Africans have imbibed Western ways of life so much that they have become almost part and parcel of their lives. Real-life experiences have shown this to be 
accurate, and it is evident in African styles of doing things. Africa's contact with the West was crucial in influencing their tradition, culture, and folklore. Akama, Hagen and Whaanga-Schollum (2019) stated that there is much risk caused by colonialism on indigenous cultures, which has made it challenging to design local practices in communities that are already polarized.

Colonialism has resulted in assimilation (and adulteration) of the rich array of values and cultural identity of the Mende folk arts. Folklorists such as Sone (2018) advocated for the marginalization of oral literature as an academic discipline in Africa to be remedied because every knowledge-led development strategy of any nation must have a solid folklore core of humanistic understanding and humane values. Folk tradition has become conceptually modern and literary through its accessibility in contemporary society. Zipes (as cited in Anttonen, Forselles and SalmiNiklander, 2018) noted regarding the Grimm Brothers and their fairy tales that literary representations are supposed to be similar to oral tradition, incorporating its style and themes to meet changes that appeal to a growing middle-class audience, particularly in contemporary society.

Sibani (2018) gave many insights into how self-identity and human emotions are embedded in oral tradition. As such, the enjoyment of folklore performance depends on originality in style and the instruments used by the practitioners. Because of this diffusion, the pleasure of Mende folklore is not asserted. This thought was confirmed by Falola and Akinyemi (2020). They reported that the diffusion of icons and aesthetic elements, such as music and fashion, came from different African sources that were not African. This situation has nurtured an interest in the practice of folk literature. It has further generated questions regarding the performance, uses, and practitioners of the genre.

The study identified a) the common practitioners of Mende folk literature and b) examined the uses of Mende folk literature in South-Eastern Sierra Leone.

\section{Literature Review}

This review looks at the following:

1. Performance versus practitioners of folk literature, and

2. Uses of Folk literature.

\subsection{Performance versus practitioners of folk literature}

The preservation and performance of folk literature have received widespread attention from several scholars (McDougall, 2019; Slater, 2016; Haring and Turin, 2013; Gemeda, 2012; Finnegan, 2012). Finnegan (2012) states that there is a connection between the transmission and the very existence of folk literature; without its oral realization and direct rendition by a performer, an oral piece cannot easily be said to exist. In addition, Ben-Amos and Goldstein (2013) claimed that the notion of performance is central to the study of folklore as communication. Through the study of performance, folklore can integrate its scientific and humanistic aims in a forward-looking way. Finnegan (2012) calls it the significance of the actual performance and states that oral literature, by definition, is dependent on a performer who formulates it in words on a specific occasion, and she emphasizes that there is no other way in which this kind of literature can be realized as a literary product except it is performed. She further states that sub-genres like proverbs have been observed to be a common practice of the elderly. Manieson and Mireku-Gyimah (2012) state that despite the changing nature of the audience of African oral literature, the success of an oral performance is still dependent on both the skilled performer and the audience. The elders practise other forms like stories, jokes, and proverbs, which require justifying (Manieson and Mireku-Gyimah, 2012). Bronner (2019) relates the quest for practitioners and or performers to safeguard the old ways and lore before being destroyed by the new way of life. This concern points to the degree to which field workers could be instrumental if they go into the field where folklore or musicological practices happen and to find practitioners who would document and record the oral performances in the form of verbal jokes, proverbs, contemporary legends, or nursery rhymes, songs, instrumental tradition, material culture, 
building techniques, or ritual practices like secret society litigations and funerary elaborations. As a way of description, Bendix and Hasan-Rokem (2014) assert that the professional folk performers have generally been from the 'lower castes. In indigenous cultures, each community of performers has a different caste name, but there are also generic terms for a diverse cast of performers. This study exemplifies the nature of performing castes in contemporary Mende culture.

\subsection{Uses offolk literature}

Folk literature has profound uses in contemporary societies. African folk literature is a source of a sense of identity (Mieder, 2015). It is a rich source of asserting the consciousness of traditional values and ways of life. In contemporary societies, literate groups have traced the oral traditions of their past to identify themselves with the values embedded in folklore. Mieder (2015) referred to this when he stated that students connect their own cultures to others and past beliefs and values to contemporary ones. Sánchez-Camus (2011) supports this view by saying that live-performance practices can produce identifiable new works when performance is integrated with the local context. Folk material culture is an essential source of inspiration (Stefano and Davis, 2016).

Although Todorov (in Leon, 2013) argues that modern folk literature no longer contributes to building people's character, folk literature has been known to shape the behaviours of the young in most African societies. Thulla (2019) discovered that $77.3 \%$ of Temne people used songs and dances to educate and entertain, $64.7 \%$ used them as a defence against rivals, and $72.2 \%$ used proverbs to educate, while $62.7 \%$ used them to give warnings. A majority of the people used songs and dance to entertain, $52.2 \%$ used it to console, and $58 \%$ used riddles to puzzle the audience. Honeyman (2013) confirms that folklore influences the social behaviour of children in a significant way. Tales derived from the oral tradition of story-telling that appeals to the child's sense of fantasy assert a unique change in behaviour and cognition (Jackman, Beaver and Wyatt, 2014). Folk stories enable children to discover themselves and discover their identity (Sutherland, 2014; Foster, 2012).

\section{Research Method}

A qualitative research design was used for the study. Interview guide questions relating to folk practices, performance and uses were designed and used to collect information from a sample of 250 participants drawn from 50 communities in 10 Chiefdoms of 5 districts (see Table 1) and selected purposefully within the south-eastern region of Sierra Leone. Ten focus group discussions were held in 10 communities selected randomly from among the 50 communities investigated. The functional requirements for this model were:

1. The structured interviews based on age, status, gender, and other factors contributing to differences in behaviour and perception within the communities were held to generate quick, easy, and cheap but structured responses from participants.

2. Getting close to community members and engaging in focus group discussions aided by the interview guides.

3. Openly participating, both as an observer and audience of oral performances with the community members.

Table 1 shows the distribution of participants in the study area. 
Table 1: Selected Districts, Chiefdoms, and Communities

\begin{tabular}{|c|c|c|c|c|}
\hline No & District & Chiefdom & Community & No. of Participants \\
\hline \multirow{2}{*}{1.} & \multirow{2}{*}{ Kenema } & Small Bo & \begin{tabular}{|l|} 
Blama \\
Baoma Oil mail \\
Saola \\
Jembeh \\
Kenyema \\
\end{tabular} & $\begin{array}{l}5 \\
5 \\
5 \\
5 \\
5\end{array}$ \\
\hline & & Kandu Leppiama & $\begin{array}{l}\text { Levuma } \\
\text { Gbado } \\
\text { Ngelegohun } \\
\text { Misila } \\
\text { Banda } \\
\end{array}$ & $\begin{array}{l}5 \\
5 \\
5 \\
5 \\
5\end{array}$ \\
\hline \multirow{2}{*}{2.} & \multirow{2}{*}{ Bo } & Tikonko & \begin{tabular}{|l|} 
Tikonko \\
Sembehun 17 \\
Torwama \\
Mokaba \\
Gondama \\
\end{tabular} & $\begin{array}{l}5 \\
5 \\
5 \\
5 \\
5\end{array}$ \\
\hline & & Bumpeh & $\begin{array}{l}\text { Bumpeh } \\
\text { Mopendeh } \\
\text { Mamboima } \\
\text { Taninahun } \\
\text { Mokoba } \\
\end{array}$ & $\begin{array}{l}5 \\
5 \\
5 \\
5 \\
5\end{array}$ \\
\hline \multirow[b]{2}{*}{3.} & \multirow{2}{*}{ Kailahun } & Lower Bambara & \begin{tabular}{|l} 
Panguma \\
Daru \\
Pendembu \\
Koindu \\
Tongo \\
\end{tabular} & $\begin{array}{l}5 \\
5 \\
5 \\
5 \\
5 \\
\end{array}$ \\
\hline & & Luawa & \begin{tabular}{|l|} 
Bandajuma \\
Segbwema \\
Kailahun \\
Jong \\
Buedu \\
\end{tabular} & $\begin{array}{l}5 \\
5 \\
5 \\
5 \\
5 \\
\end{array}$ \\
\hline \multirow{2}{*}{4.} & \multirow{2}{*}{ Moyamba } & Korie & $\begin{array}{l}\text { Taiama } \\
\text { Mokonde } \\
\text { Foya } \\
\text { Loponga } \\
\text { Lagor } \\
\end{array}$ & $\begin{array}{l}5 \\
5 \\
5 \\
5 \\
5\end{array}$ \\
\hline & & Kamajei & \begin{tabular}{|l|} 
Senehun \\
Baoya \\
Yenkesa \\
Rotifunk \\
Kpetema \\
\end{tabular} & $\begin{array}{l}5 \\
5 \\
5 \\
5 \\
5 \\
\end{array}$ \\
\hline \multirow{2}{*}{5} & \multirow{2}{*}{ Pujehun } & Kpanga Kabonde & $\begin{array}{l}\text { Pujehun } \\
\text { Potoru } \\
\text { Tiko } \\
\text { Gobaru } \\
\text { Bomi } \\
\end{array}$ & $\begin{array}{l}5 \\
5 \\
5 \\
5 \\
5\end{array}$ \\
\hline & & Makpele & \begin{tabular}{|l} 
Gbahama \\
Zimmi \\
Gandohun \\
Gendema \\
Masam \\
\end{tabular} & $\begin{array}{l}5 \\
5 \\
5 \\
5 \\
5\end{array}$ \\
\hline & TAL & 10 & 50 & 250 \\
\hline
\end{tabular}

In each section of the community, three categories of participants were considered: 1) key participants like village leaders and religious leaders, 2) community griots, and 3) adult participants. A snow-balling method was used to recruit a small number of participants at the start of data collection who selected other participants from among their contacts using the categories described above. 


\section{Results and Discussion}

\subsection{Objective A: Identified the common practitioners of Mende folk literature}

Regarding the common practitioners of Mende folk literature, a majority of participants revealed that the older people like the Maadeisai (grandfathers), Sowehs and Nyawaas (Bondo society leaders); Laawaas (Wonde Secret Society heads), Gafeisia (initiation masters of ceremony) and skilled performers like the Falui and Joebai (masked devils), Kelei lae moi (a drum-stick player), Ndoli ga moi (dancer), Bulu vec moi (a trumpeter), Bakalae moi (a silk drummer), Shegbla lae moi (a shekere or shegbureh player- a calabash instrument), Guuya bla (communal entertainers/singers) and Ndoma gbai moi (storyteller) mainly were accredited for the performance and practice of oral tradition. In one particular focus group discussion, an older adult stated frankly:

Our older men and women were the heroes of folk literature. We cannot talk about folklore without acknowledging them. They began the idea of folklore, and they started the issue of transference of folklore. The older men and women are to be praised for their ability to remember the stories and myths of their people. These myths and legends existed among them until we were born. They passed on the values and teachings embedded therein. They also held on to the messages entailed in the stories they told. The stories were popularly told by one known as Ndoma gbai moi. Many valuable lessons were learned from the stories, songs, and games of practitioners of folk tradition. The lessons learned were frequently referred to in discourses relating to moral conduct and behavioural change.

Even though the interviews showed that practitioners of Mende folk literature were varied, a majority agreed that most Mende folk practitioners performed on occasions like marriages and funeral ceremonies. An elderly female participant explained that Mende people hardly now have people they would call 'specialists' of Mende folk practices like her grandparents, who were, 'mu maada ni' (our grandfathers), respected for their knowledge of Mende oral tradition and culture.

In addition, some participants stated that a small category of people was known to exploit unique kinds of Mende folk literature. They noted that some folklore genres were confined mainly to griots, freelancers, panegyric poets and oral singers and dancers. These practitioners were mostly limited to a particular societal category, mostly connected to the upper elitist class like Laawaas, Gafeisia, Sowehs and Nyawaas (Winde/Bondo leaders). Due to their respected status in society, chiefs were frequently invited to perform in courts and squares to amuse their guests. The praise singers mainly were hired to sing songs of praise for chiefs and the chief's council.

Regarding the question on the personality of Mende folk practitioners, it was revealed during focus group discussions that the community folk practitioners were famous entertainers who performed to the audience's amusement. The focus group discussions revealed that these practitioners were regarded as 'numoinasia tu loo go' (skilled performers), men and women, with families, having special, almost saintly, personalities, who mostly lived on the tokens they received for their oral performances from the community people.

Even though there were particular kinds of people who performed certain forms of folklore in the communities, some other oral forms like 'Ndayaa weisia' (satirical songs), 'tolowoi sia' (songs of jealousy), and 'jabiyei' (songs meant to annoy others) were primarily performed on occasions for particular purposes by certain persons or groups of persons. An aged participant related during a focus group discussion that:

We now have remained only social songs and household story-telling sessions, performed primarily by children. Others like ceremonial songs, praise songs, and proverbs have particular men and women like the village 'Sowehs' and 'Nyawaas' respectively, who perform them. With the coming of civilization and things like Okada (commercial bike) riding, film watching, and the likes, our people no longer focus on folklore, especially the young boys and girls. Before now, we had the oral performers for story-telling; for instance, they would gather our children around a ring of a burning fire and us, on the moon-lit night, and tell stories which embed valuable lessons for both young and old, those stories served as 
entertainment, unity, and a means of education, the stories were usually told by the oral performer who sat in the middle of a ring-like circle. At the same time, the audience surrounded them to listen; the audience was typically made up of both male and female, young and old, who complimented the performer's efforts by singing a chorus or by clapping. I was a member of numerous audiences of storytelling in this community since I was young; unfortunately, today, these young folks have little or no interest in story-telling, least to talk of riddles and proverbs, they prefer to watch movies on their mobile phones or televisions rather than sitting and listening to stories about their heritage.

Regarding the performance of the primary forms of Mende folk literature, a tribal headman said that the oral performer (Ndomabgai Moi) would generally greet the audience and begin the story with an introduction that would amuse the audience. Moreover, after drawing the audience's attention, s/he would start by telling the anticipated lessons learned from the story, for example, 'to be greedy is not good...' Sometimes, the Ndomabgai Moi would begin the story with a song, and the audience was made to discuss the most exciting aspects of the story in the end.

Most participants disclosed that local authorities used proverbs and riddles like the chiefs and societal heads such as the 'laawaas' and the 'gafeisia', which put them under folk speeches.

In addition, the discussions revealed that during occasions and ceremonies, the practitioners were manned by a body of performers (nugaa ti yó loli blaa), say, for instance, the griots, with a leader who coordinated their activities. They determined the kind of story or song that was suitable for a particular type of occasion. In this sense, they became a unified force when once they recognized themselves as one group. A young adult participant said:

I enjoyed the performers whenever they acted as one group. The leader is usually the marshal. He gave orders to the stages of performance as the stories went by. He determined when a performer entered the performance, and at certain times, he even decided what the performer must say. Practitioners could perform very well whenever they performed on their own. However, when once they appeared in a group, they never acted entirely by themselves. For instance, if the 'joebai' and the 'falui' appear in the village square to perform, they depict unison and make spectacular performances. The leader of the group has a significant influence on the outcome of the performance.

Apart from performances with large audiences, some family and household level performances took place. The practitioners were made up of both males and females. Sometimes, a female practitioner could sing to amuse a suitor or scare away their contending partners.

The discussions also revealed that because young people were found to be uninterested in the folklore and culture of their people, Ndoma gbai moi sia told stories that provoked a change in the youth. Famous singers were revealed to sing songs of praise, and songs that scorned the excesses of individuals and society as a whole.

\subsection{Objective B: Examined the uses of Mende folk literature in South-Eastern Sierra Leone}

The findings regarding the uses of Mende folk performance revealed that folk performances formed an integral part of the social, cultural, and political fabrics of the Mende people of South-eastern Sierra Leone. It fulfilled entertainment needs and unified the community. The focus group discussions revealed that traditional oral performances also served to honour elders of the community, honouring the dead, and were performed at ritual ceremonies. Even though few participants agreed that various forms of Mende folk literature were performed at differing occasions in the communities, there were inconsistencies regarding the frequency of performances in the communities and recognized practitioners of the folk arts.

In addition, most participants said that songs and dances were performed on special occasions and could sometimes be sung instinctively by members of the indigenous society. Still, anyone in the community could dance. These performances were done during bird-scaring on farm fields, in forests, hunting expeditions, and on lonely roads, especially those leading to the brook or nearby 
villages. During the focus group discussions, some participants also pointed out that children sang songs on assignments, like fetching firewood for cooking at home. Participants also revealed that women were known for singing almost all songs on various occasions for diverse purposes. They indicated that women even sang songs while cooking in the kitchen and are mostly found singing dirges upon the death of a loved one. A female participant said traditional songs were famously sung, but traditional dance was performed during ceremonial functions and festivals. For instance, the 'ndoligablaa' (dancers), performed during the exhibition ceremony of new initiates into the Poro and Bondo secret societies. Also, songs and dances were revealed to go hand in hand during coronation ceremonies in Mendeland. However, participants also indicated that dances were sometimes performed at household levels, primarily for pleasure or enjoyment.

Moreover, participants in the focus group discussions revealed that the performance of Mende folk literature was contingent upon upholding folkways. Some of these folkways highlighted were rituals and ceremonial functions like a paramount chief coronation and burial ceremonies. The women often sang praise songs to welcome the arrival of new initiates of the Bondo and Poro secret societies. Equally so, on the day of departure for the society bush, women sang solemn songs of courage and told stories about past heroes with outstanding levels of bravery.

A 35-year-old female participant said that people in their village, especially the females, viewed dancing to attract attention from men and defend against rivals. As the dialogue continued, a male participant mentioned dances being performed by people when they were excited about something or someone or used to relieve boredom during repetitive tasks like digging or planting seedlings. He went on to explain that:

Sometimes, people dance to express their happiness about an achievement, just the other day, Ngo Vibbie was dancing outside the house to show his joy for his wife has delivered a bouncing baby boy. Aunty Saffie kept dancing around the compound because her daughter passed her school exams. We have communal groups of entertainers, called 'Guuya bla', who entertain us when we work on our farms. So, you see, all these are examples of where and when we dance in our community.

Proverbs were revealed to be primarily used in highlighting essential points when deciding facts in cases and rendering verdicts in the local courts. However, riddling sessions were shown to be occasionally exploited by children, intended to best show off their family statuses and new achievements.

It was also revealed during focus group discussions that the performance of folk literature was inextricably connected with traditional instruments like flutes, ho buluisia (drums), bakeisia (drumsticks/claves), keleisia (claves), and buluisia (horns) used in festivals and special occasions like naming and marriage ceremonies. Instruments such as potani (flute), kelei gbawei (xylophone) were reserved for secret societal ceremonies.

\subsection{Discussion}

The Mende folk practitioners of south-eastern Sierra Leone showed that older adults such as Falui, Joebai, Kelei lae moi, Ndoli ga moi, Bulu vec moi, Bakalae moi, Shegbula lae moi, Mu maada ni or Maadeisai, Sowehs, and Nyawaas; Laawaas, Gafeisia, Guuya bla, and Ndoma gbai mi were the common practitioners of Mende folk literature. This result agrees with several studies by folk literature researchers. Finnegan (2012) and Manieson and Mireku-Gyimah (2012) stated that sub-genres like proverbs had been a common practice of the elderly.

The findings regarding the uses of Mende Folk literature showed that Mende folk literature served as a source of cultural identity and inspiration (Sibani, 2018; Foster, 2014). Thulla (2019) discovered that Temne folk literature is used to educate, entertain, and defend against rivals. Further, folk literature is used to warn and console but also to puzzle the audience. According to Honeyman (2013), folklore could influence children's social behaviour in a significant way. 


\section{Conclusion}

This study has demonstrated that older people like the Maadeisia, Sowehs and Nyawaas, Laawaas and skilled performers like Falui, Joebai, Kelei lae moi, Ndoli ga moi, Bulu vec moi, Bakalae moi, Sheglaa moi, Gafeisia, Guaya bla and Ndoma gbai moi are the common practitioners of Mende folk literature. Mende folk literature has served mainly as a medium of cultural identification and inspiration. It has been used to entertain, warn, console, puzzle the audience and defend against rivals. Furthermore, folk literature is used to influence the social and cognitive behaviour of the Mende people positively.

\section{Acknowledgements}

The researchers are indebted to the members of the communities of the study area, particularly Pa. Vibbie, Yeasatta, Nyapoi Jattu, Mamie Moijama and Kinnie Adu for helping to interpret specific words and ideas during the interviews and discussion sessions.

\section{References}

Akama, Y., Hagen, P., \& Whaanga-Schollum, D. (2019). Problematizing replicable design to practice respectful, reciprocal, and relational co-designing with indigenous people. Design and Culture 11(1), 5984, doi: 10.1080/17547075.2019.1571306

Anttonen, F., Forselles, M. C. M., \& Salmi-Niklander, K. (2018). Oral tradition and book culture. Studia Fennica Folkloristica, 24(24), Helsinki. Retrieved from https://doi.org/10.21435/sff.24

Ben-Amos, D., \& Goldstein, K. S. (Eds.). (2013). Folklore: Performance and communication (Vol. 40). Walter de Gruyter; Germany.

Bendix, F. R., \& Hasan-Rokem G. (2014). A Companion to folklore. John Wiley \& Sons Inc: New York, United States.

Bronner, J. S. (2019). The oxford handbook of American folklore and folklife studies. Oxford, England: Oxford University Press.

Falola, T., Akinyemi A. (2021). The western journal of black studies Vol. 35-36. Black Studies Program: Washington State University Press.

Finnegan, R. (2012). The perception of African oral literature. Cambridge: Open Book Publishers.

Foster, J. A. (2012). The use of folk literature by foreign language teachers to promote positive social behaviours. Minnesota, USA: Hamline University.

Gemeda, E. (2012). African egalitarian values and indigenous genres: A comparative approach to the functional and contextual studies of Oromo national literature in a contemporary perspective (Vol. 5). Münster: LIT Verlag.

Haring, L., \& Turin, M. (2013). How to read a folktale: The 'Ibonia' epic from Madagascar. Cambridge: Open Book Publishers.

Honeyman, S. (2013). Consuming agency in fairy tales, childlore, and Folk literature. London: Routledge.

Jackman, H., Beaver, N., \& Wyatt, S. (2014). Early education curriculum: A child's connection to the world. Boston, USA: Cengage Learning.

Leon, R. (2013). The role of oral literature in moral development. Oxford, England: Oxford University Press.

McDougall, A. C. (2019). The decolonization of print, digital, and oral spaces in Jordan Abel's Injun. Canadian Literature, (239), 87-184.

Manieson, A. A., \& Mireku-Gyimah, P. B. (2012). The changing audience of the oral performance in Africa: The Ghanaian experience. Journal of Communication and Culture, 3(3), 1-11.

Mieder, W. (2015). Tradition and innovation in folk literature. London: Routledge, doi.org/10.4324/9781315673677.

Sánchez-Camus, R. (2011). Applied live art: Co-authorship in socially engaged and site-responsive performance practice. (Doctoral dissertation, Brunel University School of Arts, London, 2011).

Slater, N. (Ed.). (2016). Voice and voices in antiquity: Orality and literacy in the ancient world, vol. 11. Netherlands: Brill.

Sibani, C. M. (2018). Impact of western culture on traditional African society: Problems and prospects. International Journal of Religion and Human Relations, (10)1, 56-72.

Sone, E. M. (2018). African oral literature and the humanities: Challenges and prospects. Humanities, 7(2), 30, doi.org/10.339o/h7020030. 
Stefano, M. L., \& Davis, P. (2016). The Routledge companion to intangible cultural heritage. London: Routledge, doi.org/10.4324/9781315716404.

Sutherland, Z. (2014). Understanding Children' in Children \& Books...

Thulla, P. F. Y. (2019). Folk literature and its effects on the social behaviour of the Temne in northern Sierra Leone. (Doctoral Dissertation, Institute of Languages and Cultural Studies, Njala University, Sierra Leone, 2019). 